Gender Trouble: Feminism and the Subversion of Identity Judith Butler

Routledge: London 1990

ISBN $0415900433 \mathrm{Pbk} £ 8.99$

ISBN $0415900425 H b k £ 30.00$

A book that comes with nuggets of unstinting praise from such names as Harding, Haraway, Scott and Spivak printed on its cover is bound to excite expectations - and perhaps bound to disappoint them as well. These writers have found it authoritative, brilliant, innovative, startling, lucid, witty, provocative, engaging, subversive, powerful and constructive. With some reservations about its lucidity, I think I would agree with all of these.

The book is concerned with exploring the ways in which binary gender identities are presumed to flow from given biological sex and to require compulsory heterosexuality. She takes up the writings of a number of, mainly French, theorists: Simone de Beauvoir, Jacques Lacan, Luce Irigaray, Julia Kristeva, Monique Wittig, mobilizing Michel Foucault's critique of the 'repressive hypothesis' against the psychoanalytic notion of a polymorphous sexuality 'before' the law of heterosexual civilization.

At the beginning of the book, Butler has some trenchant comments on the tendency of feminist theory to seek a universal basis for feminism. "The notion of a universal patriarchy has been widely criticized in recent years for its failure to account for the workings of gender oppression in the concrete cultural contexts in which it exists ... That form of feminist theorizing has come under criticism for its efforts to colonize and appropriate nonWestern cultures to support highly Western notions of oppression' (p. 3). On this basis, she questions 'the political assumption that there must be a universal basis for feminism, one which must be found in an identity assumed to exist cross-culturally' (p. 4). Following the ideas of Michel Foucault, she argues for a feminist genealogy 'to trace the political operations that produce and conceal what qualifies as the juridical subject of feminism' (p. 5).

Yet, in the bulk of her own analysis of the 'power regimes of heterosexism and phallogocentrism' (p. 32), she completely ignores these strictures on globalizing theory. 'Gender can denote a unity of experience, of sex, gender and desire, only when sex can be understood in some sense to necessitate gender - where gender is a psychic and/or cultural designation of the self - and desire where desire is heterosexual and therefore differentiates itself through an oppositional relation to that other gender it desires' (p. 22). And she says, 'the "unity" of gender is the effect of regulatory practice that seeks to render gender identity uniform through compulsory heterosexuality' (p. 31), despite the fact that she is aware that there exist societies with radically different regimes of gender and of desire. The point of Foucault's approach is surely to give an historical specificity to what Butler calls 'the compulsory order of sex/gender/desire', to show that it is a peculiar feature of our own societies that sexuality has become 'the truth of our being' and the basis of our identity. Feminists from the non-Western world have often made the same point, in very different theoretical terms: that sexuality is not always central to women's oppression and Western women who put it top of the agenda are not speaking for feminism world-wide.

I find Butler's use of the sex/ gender distinction confusing. This distinction is mainly used in certain sociological, historical and psychological circles in the English-speaking world; it does not sit well with any of the French work that Butler engages with. Those writers in the French tradition who have problem- 
atized the category of 'woman' have not used the term gender. What they have done is to question whether the biological category 'woman' has any stable social significance, not to question the biological category as such. Those in this French tradition, like Jacqueline Rose or Jane Gallop who have written about the "constructed status of sexual difference' and its contradictions (p. 28), have not been referring to 'sex' in the biological sense of the sex/gender distinction. Indeed, Butler quotes Foucault as saying 'the notion of "sex" made it possible to group together, in an artificial unity, anatomical elements, biological functions, conducts, sensations, and pleasures and it enabled one to make use of this fictitious unity as a causal principle, an omnipresent meaning' (p. 92). It is precisely this fictitious unity that the sex/gender distinction was designed to disrupt. If, as Butler claims, 'the ostensible natural facts of sex are discursively produced by various scientific discourses' (p. 7), what follows is not that sex was 'gender all along' (p. 8), but that both 'sex' and 'gender' are meaningless. If, on the other hand, you reject her principled antifoundationalism (which is merely asserted here) and define 'sex' as whatever may eventually turn out to be the difference at the basis of sexual reproduction, then you open up a space for the critique of gender, including 'the ostensible natural facts of sex' of current scientific fumblings. Seeing the body as merely a discursive construction is not the only way of transcending mind/body dualism.

We are then left with what is, to me at any rate, a much more interesting substantive issue: in a world where there is a 'compulsory order of sex/gender/desire', what are the subversive possibilities of overt hermaphrodism, from one side, or butch-femme lesbian identities, from the other? Here Butler offers some incisive criticisms of Julia Kristeva, a discussion of Foucault's comments on the memoires of the hermaphrodite Herculine Barbin, an exploration of Monique Wittig's lesbian-feminist strategy. All these solutions, she says, are self-defeating because they presuppose and therefore consolidate the very order they appear to contest. The way forward, instead, involves recognizing that gender attributes are performative rather than expressive. Parodic performances, such as drag and the stylization of butch and femme can reveal this, and so cause the kind of gender trouble that Butler wants to make.

\section{Mary McIntosh}

